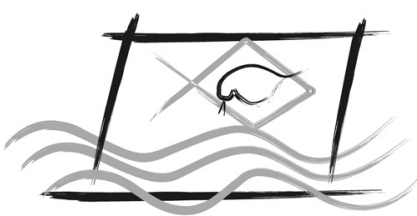

ECOTOX - BRASIL

\title{
Analysis of Cholinesterase Enzyme Activity in Rineloricaria kronei from Coastal Rivers in Southern Brazil
}

\author{
S.J. Carvalho ${ }^{1}$, M.S. Menezes ${ }^{2} \&$ A.T.B. Guimarães ${ }^{3 *}$ \\ ${ }^{1}$ Positivo University, Biological Sciences Department, Curitiba - PR, Brazil. \\ ${ }^{2}$ Federal University of Paraná, Palotina - PR, Brazil. \\ ${ }^{3}$ Federal University of Paraná, PG of Acquaculture and Sustainable Development, Palotina - PR, Brazil. * anat@brturbo.com.br
}

(Received November 22, 2011; Accept February 27, 2013)

\begin{abstract}
Levels of environmental pollution are commonly assessed via biomarkers, one of which is the activity of the cholinesterase enzyme. This study analyzed activity of cholinesterase in muscles samples of Rineloricaria kronei fish in order to assess levels of anticholinesterasic pollution in coastal rivers of the Serra do Mar mountain range in southern Brazil. A total of 93 specimens were collected at six sites along the Caiuru, Pinto and Sambaqui rivers between August and November 2007. Specimens were collected via electrofishing, with a sampling effort of 50m/hour. Cholinesterase enzyme (ChE) activity was measured in extracted muscles in the laboratory and the results analyzed using one-factor ANOVA, followed by Dunnett's test. ChE activity at sites 2, 3 and 4 was similar to that observed in control specimens. Mean activity was lower than the control $(p<0.05)$

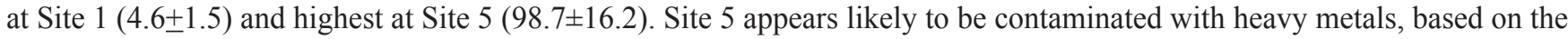
increased activity of the cholinesterase enzyme. This study suggests that the cholinesterase biomarker can be used not only to demonstrate the presence of organophosphate and carbamate pesticides, but also to indicate the presence of heavy metals.
\end{abstract}

Key Words: Cholinesterase enzyme activity, coastal stream, pesticides, heavy metals

Análise da Atividade da Enzima Colinesterase em Rineloricaria kronei de Riachos Costeiros do Sul do Brasil

\section{Resumo}

A poluição ambiental é comumente avaliada por meio de biomarcadores, como por exemplo definição da atividade da enzima colinesterase. Este estudo teve por objetivo realizar a análise da atividade da colinesterase presente em músculo de Rineloricaria sp. como forma de inferência de contaminação por agentes anticolinesterásicos nos rios costeiros da Serra do Mar paranaense. Um total de 93 espécimes foi coletado em seis pontos amostrais ao longo dos rios Caiuru, do Pinto e Sambaqui, entre os meses de agosto a novembro de 2007. A técnica de pesca elétrica foi utilizada, com esforço amostral de 50m/hora. Em laboratório, a atividade enzimática da colinesterase (ChE) da musculatura foi mensurada e os resultados foram analisados por meio do teste One-way ANOVA, seguido do teste de Dunnet. As atividades da ChE nos pontos 2, 3 e 4 estão em conformidade com as médias obtidas para os peixes controles. A média de atividade foi menor no ponto $1(4,6 \pm 1,5)$ e maior no ponto $5(98,7 \pm 16,2)$. $\mathrm{O}$ ponto 5 pode estar contaminado com metais pesados, baseado no aumento da atividade da enzima colinesterase. Este estudo sugere que a atividade da enzima colinesterase é um biomarcador que pode ser usado não somente para demonstrar a presença de pesticidas organofosforados e carbamatos, mas também indica a presença de metais pesados.

Palavras-chave: Atividade enzimática de Colinesterase, riachos costeiros, pesticidas e metais pesados.

*Corresponding author: Ana Tereza Bittencourt Guimarães, e-mail: anat@brturbo.com.br 


\section{INTRODUCTION}

Rivers in Brazil's Atlantic Forest biome have extremely high species diversity (Lowe-McConnell, 1999). Many of the region's species are endemic to these rivers, which are threatened by deforestation, loss of riparian vegetation, erosion, siltation, illegal sand extraction, and pollution from homes, farms, and industry. Since the health of individual animals in this ecosystem directly reflects the ecosystem's environmental integrity (Angermeier \& Karr, 1994), physiological changes in an individual may indicate environmental impacts. Identifying these changes can help mitigate impacts in the region. One such change is cholinesterase enzyme (ChE) activity, which is considered a biomarker capable of indicating the presence of organophosphate and carbamate insecticides (Sturm et al., 1999).

Acetylcholine is a neurotransmitter present in neuromuscular junctions and synapses of the autonomic nervous system, where it is responsible for transmitting signals between nerve cells (Purich \& Allison, 2002).

Cholinesterases are a family of esterases that catalyze the hydrolysis of a variety of choline esters (Purich \& Allison, 2002). Located in the pre- and postsynaptic membranes, this enzyme mainly regulates nerve signals in the synaptic cleft (Mendel \& Rudney, 1942). The enzyme is a commonly used biomarker in studies of aquatic ecotoxicology, since it is extremely sensitive to concentrations of organophosphate and carbamate pesticides. Cholinesterases are also sensitive to some heavy metals (Torre et al., 2002), which affect the peripheral allosteric site responsible for modulating enzymatic activity (Tabche et al., 2000; Tsigelny et al., 2000).

Conditions of terrestrial environments reflect in the coastal rivers. Anthropogenic activities on the river margins can produce negative effects on their ecology (Lowe-McConnell, 1999; Veiga et al., 2006). Organisms that live in these rivers are important bioindicators of water quality, and carry a record of exposure to xenobiotic compounds that is expressed in the form of various physiological and biochemical deviations from normal (Angermeir \& Karr, 1994). Native species and species that are year-round residents of these rivers are especially desirable as bioindicators of environmental impacts, since they offer a framework in which the local fauna can provide information about pollution levels (Winkaler et al., 2001). In this study we focused on the fish Rineloricaria kronei (Siluriformes).

Distributed throughout Brazil, Rineloricaria is considered a complex and taxonomically unresolved genus. Fish in the genus live attached to rocks and submerged branches, often burying themselves in the sand so that only the eyes are exposed (Barreto \& Aranha, 2005; Covain \& Fisch-Muller, 2007). They are herbivores, with mouths and teeth adapted to scraping river substrates for algae, detritus, and even wood (Oyakawa et al., 2006; Covain \& Fisch-Muller, 2007). As permanent residents of coastal rivers, they are exposed to pollutants there year-round.
In this study we quantified the activity of cholinesterase in muscle samples of Rineloricaria kronei, with the aim of identifying possible anticholinesterasic pollution at five sampling sites in a coastal river of the Serra do Mar in Paraná, southern Brazil.

\section{MATERIALS AND METHODS}

\section{Collected samples}

Sampling was carried out in the Pinto River, the Caiuru River (a tributary of the Pinto), and the Sambaqui River, all of which are located in the township of Morretes, Paraná (Fig. 1). The sampling sites were located in rural areas where anthropogenic impacts include small-scale farming and domestic sewage runoff. Six sites were established as follows:

- Site $1\left(25^{\circ} 34.360^{\prime} \mathrm{S} 48^{\circ} 53.005^{\prime} \mathrm{W}\right)$ was located on a stretch of the Caiuru River with a rocky riverbed and several small waterfalls. In August 2007 part of the riverbed at this site was cemented in order to protect a pipeline that crosses the river underground.

- Sites 2 and 3 ( $25^{\circ} 32.746^{\prime} \mathrm{S} 48^{\circ} 51.856^{\prime} \mathrm{W} ; 2^{\circ} 32.195^{\prime}$ $\mathrm{S} 48^{\circ} 50.836^{\prime} \mathrm{W}$ ) were located in stretches of the Pinto River where the substrate was mostly composed of boulders and the current was moderate compared to the other sites.

- Site 4 ( $\left.25^{\circ} 30.289^{\prime} \mathrm{S} 48^{\circ} 49.830^{\prime} \mathrm{W}\right)$ was located below a bridge on the Pinto River, where the river bottom was sandy and gravelly. At the time of sampling the bridge pillars had caused siltation on the right-hand bank, and most of the current ran along the left-hand bank.

- Site 5 ( $\left.25^{\circ} 27.254^{\prime} \mathrm{S} 48^{\circ} 50.720^{\prime} \mathrm{W}\right)$ was located in a stretch of the Pinto River with a sandy bottom. Prior to sampling this area has suffered significant impacts related to sand-dredging.

- A control site $\left(25^{\circ} 33.737^{\prime} \mathrm{S}, 48^{\circ} 43.986^{\prime} \mathrm{W}\right)$ was located on the Sambaqui River. Specimens from this site were used as controls.

Samples were collected every month between August and November 2007 at the five sampling sites on the Caiuru and Pinto rivers. We collected using electrofishing methods at a sampling intensity of 1 hour for every $50 \mathrm{~m}$ of river. At each site we randomly selected and sacrificed specimens of $R$. kronei, which were chilled in the field to inhibit enzyme activity and later stored in the laboratory at $-4^{\circ} \mathrm{C}$.

At all sampling sites we measured conductivity, water temperature $\left({ }^{\circ} \mathrm{C}\right)$, turbidity (TU), $\mathrm{pH}$, and dissolved oxygen (DO).

Twelve control individuals were collected at the control site in August 2007 and acclimated in 96L aquaria containing aerated water for 28 days. Aquarium water was filtered by a biofilter and an activated carbon filter, and a quarter of the water renewed weekly using a siphon. The aquarium was 


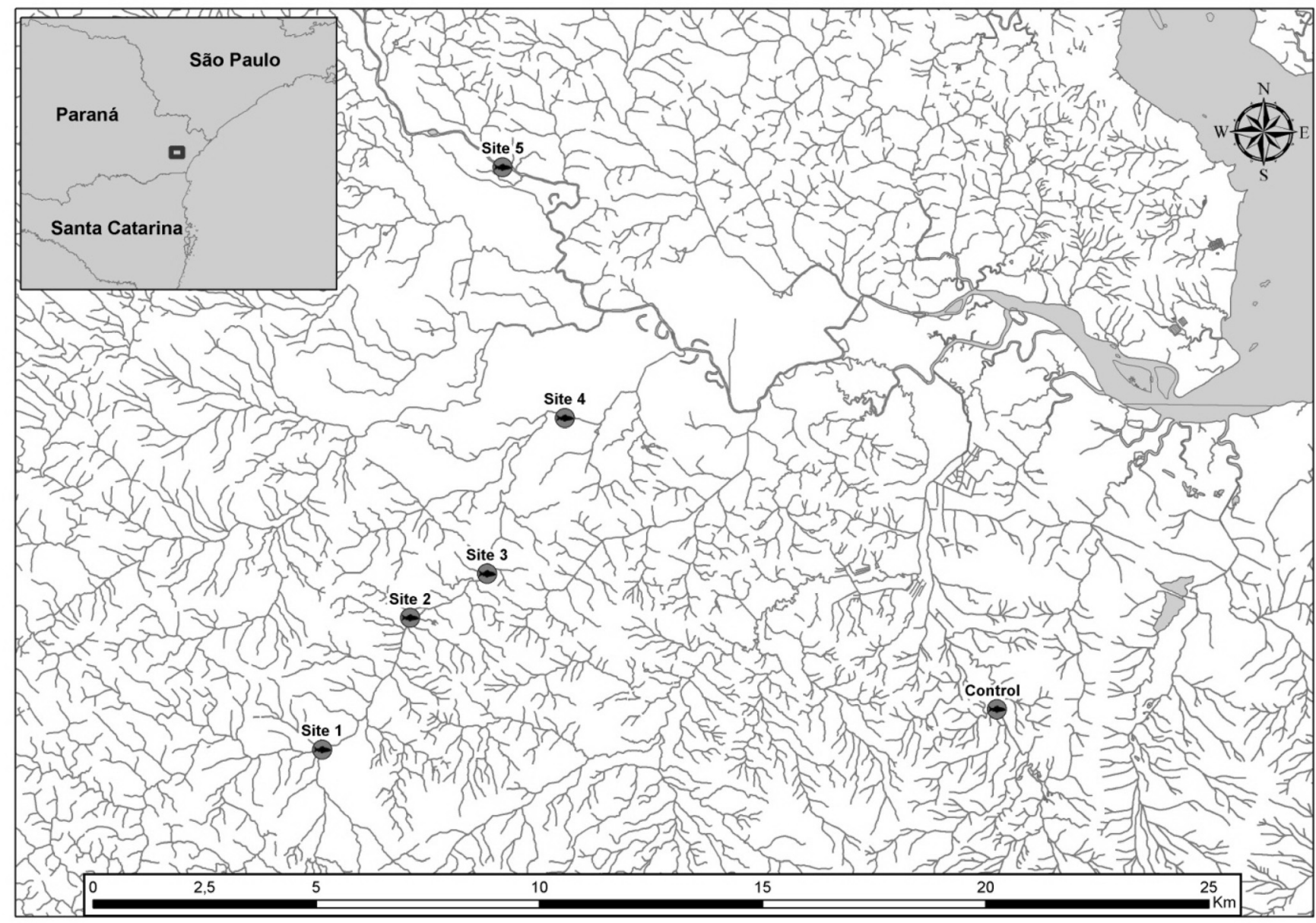

Figure 1 - A map indicating the location of sampling sites. Site 1; Site 2; Site 3; Site 4; Site 5; and the control site.

covered with screens to reduce stress. Animals were not fed during the 28-day period. Twenty-eight days have been shown to be sufficient to reestablish cholinesterase activity after any possible inhibition (Weiss, 1961).

\section{Cholinesterase activity analysis}

Analyses were carried out using the Ellman Method (Ellman 1961), modified for microplates by Silva de Assis (1998). After each monthly sampling, $R$. kronei specimens were kept frozen at $-4^{\circ} \mathrm{C}$ for one week. Specimens were then thawed but kept chilled, and muscle sampled via one perpendicular cut to the body just behind the anal orifice and another to remove the tail, leaving the entire caudal peduncle. The caudal peduncle was weighed on a digital balance and manually macerated and homogenized in a $0.1 \mathrm{M}$ phosphate buffer solution with a $\mathrm{pH}$ of 7.4. Bony plates were removed, weighed, and subtracted from the weight of the entire caudal peduncle.

The macerated muscle was stored inEppendorftubes, centrifuged at $10,000 \mathrm{rpm}$ at $<5^{\circ} \mathrm{C}$ for 10 minutes, and the supernatant liquid decanted for later use to assess enzymatic activity.

To determine the concentration of ChE, samples were diluted at 1:10 in a $0.1 \mathrm{M}$ phosphate buffer solution, and $50 \mu \mathrm{L}$ of the diluted samples then placed a microplate well. To these samples we added $50 \mu \mathrm{L}$ of acetylthiocholine iodide and $200 \mu \mathrm{L}$ of (5,5'-dithiobis-(2-nitrobenzoic (DTNB) acid, and this process was repeated in three wells for each sample. Five readings were taken with a spectrophotometer at 1-minute intervals using a 450-nm wavelength. ChE activity was calculated in relation to muscle weight (mg) using the following equation (Eq. 1):

Eq. 1) $\frac{\left[m E *(t * \varepsilon * d)^{-1}\right] *\left[1 *(1 * \text { sample dilution })^{-1}\right] *[1 *(d * \varepsilon)]}{\text { muscle weight }(m g)}$

where $\mathrm{t}=$ time; $\varepsilon=$ extinction coefficient of DTNB $(1.36$ $\left.* 10^{4} \mathrm{~mL}^{*} \mathrm{nmol}^{-1} * \mathrm{~cm}^{-1}\right)$ at a $415-\mathrm{nm}$ wavelength; $\mathrm{d}=$ diameter of the microplate wells; sample dilution $=\{1 * 1 *$ $[(300 / 50) * 10]\}$.

\section{Statistical Procedures}

One-way ANOVA was used to compare the samples collected in different months at each site. All samples from each site were compared with the control samples by one-way ANOVA, followed by Dunnett's test $(\alpha=0.05)$ (Zar, 1998).

\section{RESULTS}

For characterization of sample points, we found a stability between the observed means, without statistical differences 
$(p>0,05)$ (Table 1). Thus, we consider the comparison of the samples points liable because they have similarity in their abiotic characteristics.

Only three $R$. kronei specimens were collected at sampling site 1, all of them in August. Fish from this site showed the

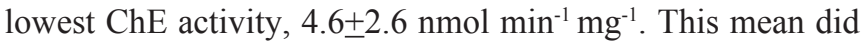
not differ significantly from those of the other sampling sites $(p>0.05)$, or from that of the control specimens $(p>0.05)$. The lack of significant differences may be the result of the low number of samples collected at this first site, and the lack of specimens from others months. This could potentially be a Type II error, which supports the null hypothesis when it should be rejected (Zar, 1998). For this reason, in order to avoid a loss of power in the analyses, data from this sampling site were excluded from the remaining analyses.

At sampling sites 2, 3, 4 and 5 we collected 28, 21, 23 and 20 specimens of $R$. kronei, respectively. As ChE activity at a given site did not vary significantly over the four months of the study (Table 2) $(\mathrm{p}>0.05)$, data from all months were combined into a compound sample for each sampling site.

Mean $( \pm$ SE) activities at sampling sites 2,3 , and 4 were $61.1 \pm 8.0,48.3 \pm 7.6$, and $75.3 \pm 12.2 \mathrm{nmol} \mathrm{min}^{-1} \mathrm{mg}^{-1}$, respectively (Fig. 2). These means are not significantly different from the mean observed in control specimens $\left(39.0 \pm 5.3 \mathrm{nmol} \mathrm{min}^{-1} \mathrm{mg}^{-}\right.$ 1) ( $\mathrm{p}>0.05)$ (Fig. 2).

Site 5 showed the highest mean cholinesterase activity. Mean activity in specimens from that site, 98.7 $\pm 16.2 \mathrm{nmol}$ $\mathrm{min}^{-1} \mathrm{mg}^{-1}$ (Fig. 2), was significantly higher than that observed in control specimens $(\mathrm{p}<0.05)$.

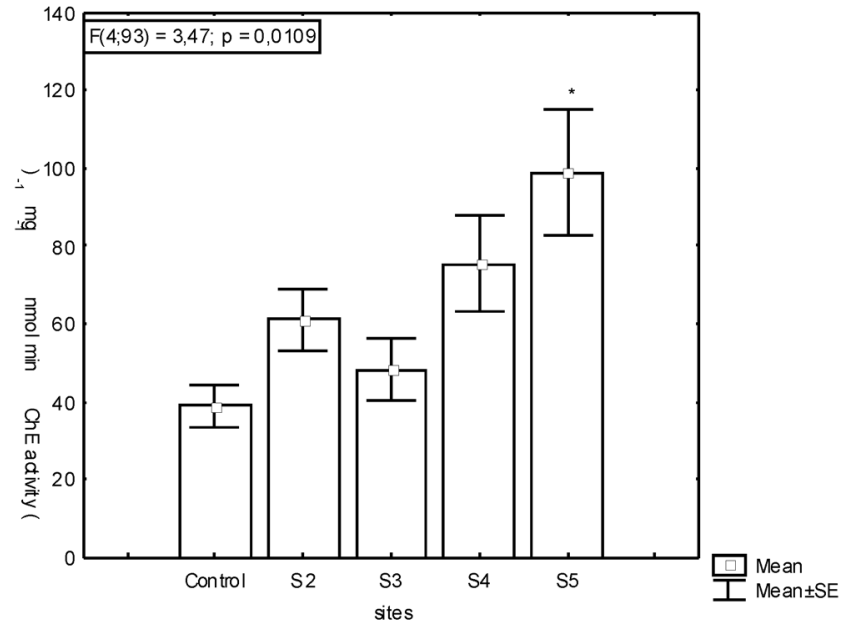

Figure 2 - Mean ChE activity $( \pm \mathrm{SE})$ in specimens collected at the sampling sites and in control specimens. Means that are statistically different from the others according to a one-way ANOVA and post-hoc Dunnett's test at the $\mathrm{p}<0.05$ level are marked with an asterisk $\left(^{*}\right)$.

\section{DISCUSSION}

The aim of this study was to quantify the range of variation of activity of cholinesterase in muscles samples of the fish $R$. kronei, a year-round resident of coastal rivers, and to assess the biomarker's effectiveness in detecting different types of environmental pollution. There are two types of cholinesterases in vertebrates. Butyrylcholinesterases are more frequent in nerve endings associated with muscles and prefer

Table 1 - Descriptive statistics (mean and standard deviation) of water attributes at the sampling sites. P-valor obtained in the comparison between sample points by One-way ANOVA.

\begin{tabular}{l|cccccc}
\hline & $\begin{array}{c}\text { No. of fish } \\
\text { sampled }\end{array}$ & Conductivity & $\begin{array}{c}\text { Temperature } \\
\left({ }^{\circ} \mathrm{C}\right)\end{array}$ & $\mathrm{pH}$ & $\begin{array}{c}\text { Dissolved } \\
\text { oxygen }\end{array}$ & Turbidity \\
\hline Site 1 & 3 & $27.8 \pm 23.0$ & $17.6 \pm 1.9$ & $7.2 \pm 0.5$ & $6.2 \pm 3.3$ & $0.3 \pm 0.1$ \\
Site 2 & 27 & $22.3 \pm 18.4$ & $18.5 \pm 2.2$ & $7.7 \pm 0.5$ & $6.4 \pm 3.5$ & $1.3 \pm 1.6$ \\
Site 3 & 21 & $28.4 \pm 21.4$ & $19.3 \pm 2.1$ & $7.3 \pm 0.8$ & $6.4 \pm 3.4$ & $0.9 \pm 0.9$ \\
Site 4 & 23 & $28.4 \pm 21.4$ & $19.9 \pm 2.6$ & $7.1 \pm 0.9$ & $5.9 \pm 2.2$ & $1.0 \pm 0.9$ \\
Site 5 & 19 & $28.1 \pm 24.3$ & $19.4 \pm 3.0$ & $7.1 \pm 0.8$ & $6.0 \pm 3.0$ & $0.8 \pm 0.2$ \\
Control Site & 8 & $28.1 \pm 3.9^{*}$ & $18.8 \pm 0.6$ & $7.2 \pm 0.2$ & $6.3 \pm 0.1 *$ & $0.9 \pm 0.1^{*}$ \\
\hline $\mathbf{p}$ & \multicolumn{7}{r}{$\mathbf{p}$} & $>0,05$ & $>0,05$ & $>0,05$ & $>0,05$ & $>0,05$ \\
\hline
\end{tabular}

Table 2 - Sample size and mean $\left( \pm\right.$ SE) cholinesterase enzyme activity (nmol $\left.\mathrm{min}^{-1} \mathrm{mg}^{-1}\right)$ in specimens collected over four months (August-November 2007$)$ at five sites on the Caiuru and Pinto rivers. The last column shows the p-value of a one-way ANOVA comparing the monthly means at a given site.

\begin{tabular}{c|ccccccccc}
\hline \multirow{2}{*}{ Site } & \multicolumn{2}{|c}{ August } & \multicolumn{2}{c}{ September } & \multicolumn{2}{c}{ October } & \multicolumn{2}{c}{ November } & $\mathrm{p}$ \\
\cline { 2 - 7 } & $\mathrm{n}$ & Mean+SE & $\mathrm{n}$ & Mean+SE & $\mathrm{n}$ & Mean+SE & $\mathrm{n}$ & Mean+SE & \\
\hline Site 1 & 3 & $4.6 \pm 1.5$ & 0 & $\mathrm{~ns}$ & 0 & $\mathrm{~ns}$ & 0 & $\mathrm{~ns}$ & - \\
Site 2 & 5 & $64.0 \pm 18.2$ & 7 & $75.2 \pm 23.4$ & 6 & $59.9 \pm 5.8$ & 10 & $44.5 \pm 12.5$ & $>0.05$ \\
Site 3 & 10 & $44.8 \pm 9.2$ & 2 & $88.1 \pm 57.5$ & 4 & $25.7 \pm 13.4$ & 5 & $57.6 \pm 10.5$ & $>0.05$ \\
Site 4 & 10 & $51.1 \pm 11.0$ & 4 & $117.6 \pm 59.0$ & 0 & $\mathrm{~ns}$ & 9 & $83.4 \pm 11.6$ & $>0.05$ \\
Site 5 & 8 & $159.9 \pm 81.9$ & 4 & $122.3 \pm 57.4$ & 0 & $\mathrm{~ns}$ & 8 & $101.8 \pm 14.4$ & $>0.05$ \\
\hline
\end{tabular}


substrates in low concentrations, while acetylcholinesterases are more frequent in the central nervous tissue and act when there is substrate in excess (Marcel et al., 1998). Our study of cholinesterase activity focused on the muscles of fish because butyrylcholinesterases are more sensitive to low substrate concentrations (Metzler, 2003) and because the abundance of muscle tissue facilitates analyses of enzymatic activity and permits greater precision.

Analysis of the data revealed that the lowest values of enzymatic activity were recorded at Site 1 , which indicates inhibition of the ChE enzyme. This could be the result of recent construction at this site to encase an underground pipeline in concrete, which may have caused hydrocarbon and/or heavy metal pollution. Both are specific anti-enzyme ChE pollutants, and their pathways with $\mathrm{ChE}$ have not been fully elucidated (Torre et al., 2002). However, some authors have hypothesized possible pathways for heavy metals. Tabche et al. (2000) observed that high concentrations of nickel $(\mathrm{Ni})$ inhibit cholinesterase, suggesting that the metal bonds to the structure of the enzyme and reduces its affinity for the substrate. Thus we cannot discard the possibility that pipeline-derived pollutants affected results in this stretch of river, despite the very low sample size at this site.

Another hypothesis to explain the inhibition of cholinesterase enzymes is pollution from insecticides and herbicides used in subsistence agriculture along the Caiuru River. These pesticides reach rivers mostly through water transport, either via surface flow or leaching through the soil (Campagna et al., 2006). Pollution from tomato crops was found in groundwaters and nearby rivers by Veiga et al. (2006), who showed that a large proportion of the pesticides used in agriculture do not remain on agricultural lands. The low sample size at Site 1 makes any discussion of cause and effect speculative, however, and testing these ideas in a robust fashion will require additional sampling.

Mean activity at sites 2, 3 and 4 was not significantly different from that found in the control specimens, suggesting that these sites may not have suffered anticholinesterasic pollution, at least at levels that are detectable with our methods.

The date from Site 5 suggested that cholinesterase is being activated there. Similar results were reported by Tabche et al. (2000), who noted that low concentrations of nickel ( $0.01 \mathrm{mg}$ $\mathrm{kg}^{-1}$ and $\left.0.1 \mathrm{mg} \mathrm{kg}^{-1}\right)$ increased cholinesterase enzyme activity. There is another peripheral allosteric site which is responsible for modulating enzymatic activity (Tabche et al., 2000; Tsigelny et al., 2000), and the presence of small quantities of divalent metals bond to this site and stimulate enzyme activity (Tsigelny et al., 2000). Higher concentrations, however, interfere in enzyme-substrate interactions at the cholinergic site, inhibiting activity (Marcel et al., 1998; Tabche et al., 2000).

In addition, Alves (2003) noted that increased enzyme activity may indicate a compensatory effect of previous exposure to organophosphates and/or carbamates. A study by Tsuda et al. (1993) showed that these compounds reach peak pollution after 24 hours of exposure, after which fish's bodies begin a process of detoxifying and excreting. While it is possible that Site 5 is polluted with a divalent heavy metal such as nickel, this hypothesis remains untested, since we did not carry out analyses to detect divalent heavy metal pollution in the area.

Through the measurement of fish cholinesterase activity in the coastal streams it is possible to observe areas with different degrees of anthropogenic impacts. Low cholinesterase activity was observed in specimens from the first site, suggesting inhibition related to the pipeline that crosses the river there or to the leaching of pesticides and herbicides from nearby farms.

In the Pinto River, sites 2, 3 and 4 showed levels of cholinesterase activity considered normal, based on the variation observed in the control data.

At Site 5 cholinesterase activity was higher, suggesting possible pollution by divalent heavy metals, which in low concentrations can stimulate $\mathrm{ChE}$ activity, or previous exposure to an anticholinesterasic agent, from which fish were still recovering.

We recommend that future analyses of cholinesterase activity be carried out together with assessments of the presence of heavy metals and pesticides in water and soils. Such a joint study would make it possible to confirm chemical pollution, as well as the biological effects of that pollution on the organisms that live in these environments.

\section{ACKNOWLEDGMENTS}

We thank the Biological Sciences Department of Positivo University and Professor Helena Cristina Silva de Assis of the Pharmacology Department of the Federal University of Paraná.

\section{REFERENCES}

ANGERMEIER P.L., KARR, J.R., 1994, Biological integrity versus biological diversity as policy directives. Bioscience, 44: 690697.

ALVES S.R.C., 2003, Respostas bioquímicas em tilápias mantidas no Rio do Braço, Joinville, SC. Florianópolis, Santa Catarina. Master's thesis, Federal University of Santa Catarina. 52 p.

BARRETO A.P. \& ARANHA J.M.R., 2005, Assembléia de peixes de um riacho de Floresta Atlântica: composição e distribuição espacial (Guaraqueçaba, Paraná, Brasil). Acta Sci. Biol. Sci., 27:153-160. http://dx.doi.org/10.4025/actascibiolsci.v27i2.1326.

CAMPAGNA A.F., ELER M.N., ESPÍNDOLA E.L.G., SENHORINI J.A., DO RÊGO R.F. \& SILVA L.O.L., 2006, Dimethoate $40 \%$ Organophosphorous pesticide toxicity in Prochilodus lineatus (Prochilodontidae, Characiformes) eggs and larvae. Braz. J. Biol., 66: 633-640. http://dx.doi.org/10.1590/S151969842006000400007.

COVAIN R. \& FISCH-MULLER S., 2007, The genera of the Neotropical armored catfish subfamily Loricariinae(Siluriformes: Loricariidae): a practical key and synopsis. Zootaxa 1462: 1-40. 
ELLMAN G.L., COURTNEY K.D., ANDRES JR. V. \& FEATHERSTONE R.M., 1961, A new and rapid colorimetric determination of acetylcholinesterase activity. Biochem. Pharmacol., 7: 88-95. http://dx.doi.org/10.1016/0006-2952(61)90145-9.

LOWE-MCCONNELL R.H., 1999, Estudos ecológicos de comunidades de peixes tropicais. EDUSP, São Paulo, 535p.

MARCEL V., PALACIOS L.G., PERUY C., MOSSON P. \& FOURNIER D., 1998, Two invertebrate acetylcholinesterases show activation followed by inhibition with substrate concentration. Biochem. J., Britain, p 329-334.

MENDEL B. \& RUDNEY H., 1942, Studies on cholinesterase 1. Cholinesterase and pseudo-cholinesterase. Biochem. J., 37: 5963.

METZLER D.M., 2003, Biochemistry: the chemical reactions of living cells. Academic Press - Elsevier Science, USA, 2 ed. 1977p.

OYAKAWA O.T., AKAMA A., MAUTARI K.C. \& NOLASCO J.C., 2006, Peixes de Riachos da Mata Atlântica. Editora Neotrópica LTDA, São Paulo-SP, 201p.

PURICH D.L. \& ALLISON R.D., 2002, The enzyme reference: a comprehensive guidebook to enzyme nomenclature, reactions, and methods. Academic Press, Amsterdam, 929p.

SILVA DE ASSIS H.C., 1998, Der Einsatz von Biomarkern zur summarischen Erfassung von Gewasserverschutzungen. Ph.D. Thesis, Technical University, Berlin, Germany, 99p.

STURM, A. SILVA DE ASSIS, H. C., HANSEN, P.-D., 1999, Cholinesterases Of Marine Teleost Fish: Enzymological Characterization And Potential Use In The Monitoring Of Neurotoxic Contamination. Mar. Env. Res. 47: 389-398. http:// dx.doi.org/10.1016/S0141-1136(98)00127-5.

TABCHE L.M., OLIVÁN L.G., MARTINEZ M.G., CASTILLO C.R. \& SANTIAGO A.M., 2000, Toxicity Of Nickel In Artificial
Sediment On Acetylcholinesterase Activity And Hemoglobin Concentration Of The Aquatic Flea, Moina Macrocopa. J. Env. Hydrol., 8: 1-10.

TORRE F.R., FERRARI L. \& SALIBIÁN A., 2002, Freshwater pollution biomarker: response of brain acetylcholinesterase activity in two fish species. Comp. Biochem. Physiol. C, 131: 271-280. http://dx.doi.org/10.1016/S1532-0456(02)00014-5.

TSIGELNY I., SHINDYALOV I.N., BOURNE P.E., SÜDHOF T.C. \& TAYLOR, P., 2000, Common EF-hand motifs in cholinesterases and neuroligins suggest a role for $\mathrm{Ca}^{2+}$ binding in cell surface associations. Prot. Sci., 9: 180-185. http://dx.doi. org/10.1110/ps.9.1.180.

TSUDA T., AOKI S., KOJIMA M. \& FUJITA T., 1993, Accumulation and excretion of organophosphorus pesticides by Carp Cyprinus carpio. Comp. Biochem. Physiol. C, 104: 275-278. http://dx.doi. org/10.1016/0742-8413(93)90035-J.

VEIGA M.M., SILVA D.M., VEIGA L.B.E. \& FARIA M.V.C., 2006, Análise da contaminação dos sistemas hídricos por agrotóxicos numa pequena comunidade rural do Sudeste do Brasil. Cad. Saúde Pública, 22: 2391-2399. http://dx.doi.org/10.1590/S0102311 X2006001100013.

WEISS, C.M., 1961. Physiological effect of Organic Phosphorus Insecticides on Several Species of Fish. Trans. Amer. Fish. Soc., 90: 143-152. http://dx.doi.org/10.1577/15488659(1961)90[143:PEOOPI]2.0.CO;2.

WINKALER E.U., SILVA A.G., GALINDO H.C., MARTINEZ C.B.R., 2001, Biomarcadores histológicos e fisiológicos para o monitoramento da saúde de peixes de ribeirões de Londrina, Estado do Paraná. Acta Scient., 23: 507-514.

ZAR, J.H., 1998. Biostatistical Analysis. Prentice-Hall, Englewood Cliffs, 4 ed., 929p. 